\title{
Results of a Quantitative Assessment of France's Garantie Jeunes Programme
}

What Target Groups, What Kinds of Support, and What Beneficiary Trajectories?

Mathilde Gaini, Marine Guillerm, Solène Hilary, Emmanuel Valat and Philippe Zamora

Translator. Patrick Hamm

\section{OpenEdition}

\section{Journals}

Electronic version

URL: http://journals.openedition.org/travailemploi/10014

DOI: 10.4000/travailemploi.10014

ISSN: $1775-416 \mathrm{X}$

\section{Publisher}

DARES - Ministère du Travail

\section{Printed version}

Date of publication: 1 March 2020

Number of pages: $31-52$

ISSN: 0224-4365

\section{Electronic reference}

Mathilde Gaini, Marine Guillerm, Solène Hilary, Emmanuel Valat and Philippe Zamora, "Results of a Quantitative Assessment of France's Garantie Jeunes Programme", Travail et Emploi [Online], Horssérie | 2020, Online since 01 March 2021, connection on 30 April 2021. URL: http:// journals.openedition.org/travailemploi/10014 ; DOI: https://doi.org/10.4000/travailemploi.10014 


\title{
Results of a Quantitative Assessment of France's Garantie Jeunes Programme
}

\section{What Target Groups, What Kinds of Support, and What Beneficiary Trajectories?"}

\author{
Mathilde Gaini, Marine Guillerm, Solène Hilary, \\ Emmanuel Valat, Philippe Zamora**
}

\begin{abstract}
France's Garantie jeunes ("Youth Guarantee", GJ) is a local support programme that targets young people who are in precarious situations and neither in employment, education, or training. It was set up in October 2013, initially on a trial basis. This article presents the results of a quantitative evaluation of the scheme. A panel survey conducted among young people who participated from the beginning of the trial in the areas first trialling Garantie jeunes reveals a very fragile population. The programme offers a high level of support, especially during the collective phase at the start. The evaluation of the scheme takes into account the fact that it was initially set up in only part of the country. Estimates concerning the participants in the first Garantie jeunes target areas indicate that the programme has had an impact on their life trajectories. It has intensified support and has had an impact on beneficiaries' employment rates, an impact that continues in the months following the end of support.
\end{abstract}

\footnotetext{
* Traduction: Patrick Hamm. Article published in French in Travail et Emploi, no 153, 2018.

We would like to thank the Garantie Jeunes Scientific Evaluation Committee, which supervised the methodology and implementation of this study and provided numerous opinions and advice. We are particularly grateful to the committee chair Jérôme Gautié as well as to Marc Gurgand, Léa Lima and Anne Fretel. We would also like to thank Deborah Cristel-Delesse, Élise Pesonel and Wali Rostam for their involvement in the first months of this evaluation, as well as Pauline Leveneur who participated in the exploitation of the data. The authors are very grateful to Patrick Hamm for translation into English and to Christine Erhel for her valuable suggestions and comments on the translation. ** The authors were all affiliated with the Directorate for the Animation of Research, Studies and Statistics (Direction de l'animation de la recherche, des études et des statistiques, DARES) of the French Ministry of Labour, at the time of writing. Contact: marine.guillerm@education.gouv.fr.
} 
Carantie jeunes is an employment assistance programme for young people aged $\checkmark 16$ to 25 who are neither in employment, education, or training ("Neets") and in a situation of financial insecurity. The aim of this innovative scheme is to remobilise young people who, in addition to their socio-demographic characteristics, have very particular individual characteristics (MENDOLIA, WALKER, 2015). A local centre (a Mission locale) dedicated to young people provides support over twelve months, in a more collective form for the first few weeks and then mainly individually. The support is built on the logic of "work first" and active intervention: the young people are encouraged to engage in multiple work situations (in the form of job "immersions", or secondments, in companies in particular) even before dealing with the various underlying obstacles to employment (problems of mobility, housing, health, etc.). The young people also receive a guaranteed stipend for twelve months, which is degressive with any job income and is capped at the level of France's RSA (Revenu de solidarité active) social welfare benefit for a single person (484.82 euros per month as of April 2018).

A quantitative evaluation of Garantie jeunes was planned from the moment it was established. Its objectives were to verify that the programme was reaching its target audience, to describe the career paths taken by the young participants and to assess its impact on their future, particularly on their integration into employment (WARGON, GuRGAND, 2013).

Enhanced support for young people from the local centre includes personalised follow-up, group workshops focusing in particular on job search techniques and life skills, and contacts with companies (in the form of job immersions, for example). In theory, the enhanced support for job seekers should improve their access to employment by helping them conduct job searches more intensively and efficiently. It prepares them for recruitment procedures and puts them in contact with companies. Given the major frictions these young people face (PISSARIDES, 2011), this helps to make the labour market more fluid. Overall, evaluations of enhanced support programmes show that they have a positive effect on the return to employment in the short and medium term and that, on the whole, they benefit young people as well as people in other age groups, but especially the groups that are most socially disadvantaged (CARD et al., 2018; PARENT et al., 2013). Several support programmes specifically targeted at young people have been evaluated in France, including, for example, the case of a trial programme for young graduates (CRÉPON et al., 2011), clubs for young job seekers living in what are called troubled urban areas (Zone urbaine sensible) (BLASCO et al., 2015) and the intensive support for young people programme (Accompagnement intensif des jeunes) of France's job centre Pôle emploi (BLACHE, GRECO, 2017). These three evaluations concluded that the schemes have a positive effect on access to employment, and particularly to long-term employment.

Garantie jeunes support features a collective phase during the first few weeks, in groups of around fifteen young people. It is, by definition, less personalised than traditional individual support, but the collective format aims to create dynamic cooperation 
among the young people (information-sharing, networks, mutual aid, etc.). The "clubs for young job seekers" experiment provided an opportunity to evaluate the impact of collective support compared to individual support. It concluded that collective support has a positive impact on participants' access to employment, particularly on their access to long-term employment (BLASCO et al., 2015). Within six months, the clubs had lifted the long-term employment rate of the young people involved by five percentage points.

The Garantie jeunes programme also includes the payment of a stipend. This represents first of all significant financial support for a population of young people in precarious situations. The payment of a stipend can however have two opposing effects on the job search. On the one hand, it should enable participants to invest in their professional development and training on a long-term basis by easing the financial constraints they face, helping to pull them out of a short-term logic that would lock them into subsistence work. On the other hand, the payment of a stipend may have a disincentive effect: beneficiaries may reduce their job-seeking efforts because they have additional income. This disincentive effect could also be reinforced by the degressive nature of the stipend with job income (starting from the first euro).

The effect of paying a stipend was examined as part of the trial of the RCA (Revenu contractualisé d'autonomie) programme carried out between April 2011 and June 2013, which involved a conditional cash transfer. Garantie jeunes fully takes into account the results of this evaluation. The RCA provided for individualized support, similar to that provided under the main national job placement programme for youth called Civis (Contrat d'insertion dans la vie sociale), but supplemented by the payment of a stipend for two years (the first year provided a monthly stipend of 250 euros, decreasing quarterly in the second year). The results of the trial highlight the disappointing impact of the RCA in terms of participants' access to employment (AEBERHARDT et al., 2014). The impact of the RCA on participants' income was too small to ease their budgetary constraints. Garantie jeunes thus used the principle of a guaranteed monthly stipend, but the amount is almost doubled, access to the programme is reserved for young people in a precarious situation, the stipend is degressive only from 300 euros of job income, and sanctions are possible in case of non-compliance with a contract that the young person signs with the local centre.

The first part of this article describes the sources and methodology used for the impact assessment. The second part presents a description of the profiles of the Garantie jeunes participants, the support trajectory in the local centres, and changes in their situation in terms of access to employment and autonomy, both while they are in the programme and in the months following their departure. The third part presents the results of the evaluation of the impact of Garantie jeunes on the beneficiaries' career paths. 


\section{Methodology and Data}

\section{Evaluation Strategy}

As with any other employment policy programme, the evaluation of the impact of Garantie jeunes consisted of comparing the situation of the beneficiaries with the "counterfactual" situation, i.e. the situation that would have prevailed for these young people if the programme had not been established. The difference between these two situations gives an assessment of the scheme's "causal impact". The counterfactual situation is by definition not known directly. It is therefore necessary to reconstruct a comparison group that is as similar as possible to the beneficiary group, which can sometimes be complex.

The evaluation of Garantie jeunes takes full account of the scheme's experimental nature. As Garantie jeunes was initially implemented in only a limited number of areas ("pilot sites"), it is possible to reconstruct counterfactual trajectories in areas that did not participate in the experiment ("control sites"). The pilot sites here correspond to the first ten areas that implemented Garantie jeunes in October 2013 (areas in phase 1 of the trial).

However, it is not possible to directly compare the future of beneficiaries of Garantie jeunes in the pilot areas with that of young people residing in the control areas who would have joined Garantie jeunes if it had been implemented in their area. This group cannot be precisely identified in the control areas. For example, it is not precise enough simply to select young people who are not in employment or who are monitored by local centres. This would amount to neglecting possible selection factors that differentiate this group from the beneficiaries of Garantie jeunes. This is actually a difficulty in evaluating social programmes generally: the participants have many characteristics that help to explain their future but which are difficult to observe directly, even using very detailed surveys. If these characteristics are ignored and "raw" comparisons are made between beneficiaries on the one hand and a group in the control sites on the other, the latter will be tainted by potentially very significant selection biases.

In order to evaluate the effect of the programme properly, it is therefore necessary to work on well-defined groups with the same characteristics measured in the same way in all the areas (pilot and control), and which therefore differ only in that some are in areas that have implemented Garantie jeunes and others in areas that have not. To this end, the evaluation of Garantie jeunes is based on the identification of young people eligible for the programme in both the pilot and control areas. The Edipe platform, an Extranet tool for identifying eligible groups, has made it possible to identify young people eligible for Garantie jeunes at local centres located in both pilot and control areas, whether or not these young people ultimately did or did not join the programme.

Furthermore, the pilot areas in phase 1 of the trial, which are the subject of the evaluation, were not selected at random and are characterised by a more difficult 
economic situation than the other areas: in 2010, the unemployment rate for young people aged 16 to 25 was $31.5 \%$, compared to $24.5 \%$ for the country as a whole. It is therefore very likely that without the implementation of Garantie jeunes, young people in the pilot and control areas would not have experienced the same trajectory. In other words, a "structural gap" between these two groups would have been observed.

To take account of this discrepancy between the estimates, the sample of eligible young people was supplemented by a sample of young people with characteristics close to those identified as eligible in the Edipe tool even if a priori they are not eligible. These young people were interviewed individually at the local centre during the reference period and were not reported as eligible in Edipe. In order to ensure that ultimately only a small number of these young people will be eligible, they were selected from among the young people living with their parents or in independent accommodation (tenant or owner). These young people will be referred to in the rest of the article as "non-eligible", even though they represent only a portion of the young people not eligible for Garantie jeunes. The "common gap" hypothesis consists of assuming that the deviation observed for "non-eligible" youth between the pilot and control areas corresponds to the gap that would have been observed for youth identified as eligible if the programme had not been implemented. This is the main hypothesis of the evaluation.

The difference-in-difference estimator is thus at the centre of the evaluation. It consists in controlling the difference between those eligible (E) in the pilot $(\mathrm{P})$ and the control (T-témoin) areas, i.e. $\bar{y}_{E, P}-\bar{y}_{E, T}$ and the structural difference estimated from "non-eligible" (NE) young people: $\bar{y}_{N E, P}-\bar{y}_{N E, T}$ The difference-in-difference estimate (noted DID) of the variable of interest thus corresponds to:

$$
D I D=\left(\bar{y}_{E, P}-\bar{y}_{E, T}\right)-\left(\bar{y}_{N E, P}-\bar{y}_{N E, T}\right)
$$

The effect measured by the difference-in-difference estimator corresponds to the average effect on all youth identified as eligible in the pilot areas, in the literature called "Intention to Treat" (ITT). However, only a portion of these youths benefited from Garantie jeunes. The Average Treatment Effect on the Treated (ATT) is a more readable and understandable indicator, since it does not depend on the rate of young people actually entering Garantie jeunes. In the absence of young people entering the programme among young people in the pilot areas and among non-eligible young people, and given the assumption that the programme had no impact on non-participants, the impact of Garantie jeunes on participants corresponds to the difference-in-difference estimator previously calculated relative to the percentage of eligible young people in the pilot areas who actually entered the scheme.

In fact, some young people from the control areas and some non-eligible young people (regardless of the area) also enrolled in Garantie jeunes. This is known as "statistical contamination". First of all, the criteria used to define non-eligible groups are not perfect predictors of non-eligibility for Garantie jeunes. In addition, non-eligible youth may have become eligible over time. Finally, due to the extension of the scope 
of the trial in January 2015, some control areas started to trial the Garantie jeunes scheme during the evaluation process.

Statistical contamination leads to a potential bias in the aforementioned differencein-difference estimator. While, like other schemes with reinforced support, Garantie jeunes has a positive effect on access to employment, statistical contamination leads to an underestimation of the impact (unless its effect on ineligible "contaminated" young people is much greater in the control areas than in the pilot areas).

To correct the statistical contamination, a first option could be to remove from the sample the control young people entered in Garantie jeunes. This option is not, however, very satisfactory. As the "contaminated" young people have particular characteristics, some of which are not observable, the samples of eligible and non-eligible young people would no longer be comparable between the pilot and control areas. Statistical contamination requires an additional hypothesis concerning the effect of Garantie jeunes on "contaminated" young people. For a variable of interest $y$, the average rate that would have been observed in the absence of statistical contamination, for example on the eligible young people in the control areas, corresponds to:

$$
\bar{y}_{E, T}-\overline{G J}_{E, T} A T T_{E, T}
$$

where $\overline{G J}_{E, T}$ corresponds to the proportion of eligible young people in a control area who have entered Garantie jeunes, and $A T T_{E, T}$ is the impact of Garantie jeunes on these contaminated youth. The common gap hypothesis that takes account of the statistical contamination is therefore written as follows:

$$
\left(\bar{y}_{E, P}-\overline{G J}_{E, P} A T T_{E, P}\right)-\left(\bar{y}_{E, T}-\overline{G J}_{E, T} A T T_{E, T}\right)=\left(\bar{y}_{N E, P}-\overline{G J}_{N E, P} A T T_{N E, P}\right)-\left(\bar{y}_{N E, T}-\overline{G J}_{N E, T} A T T_{N E, T}\right)
$$

This equality makes it possible to deduce the effect on the beneficiaries provided that a hypothesis is made concerning the impact of Garantie jeunes on "contaminated" populations. The difference-in-difference estimator relative to the rate of Garantie jeunes entry among eligible youth in the pilot areas implicitly assumes that Garantie jeunes had a nil effect on "contaminated" youth. We thus favour the hypothesis of a homogeneous impact on beneficiaries, i.e., the effect of Garantie jeunes on beneficiaries is the same for all four sub-populations. Under this hypothesis, the effect of Garantie jeunes on beneficiaries can be estimated as follows (DE CHAISEMARTIN, D'HAULTFOEUILLE, 2018):

$$
\mathrm{ATT}=\frac{\left(\bar{y}_{E, P}-\bar{y}_{E, T}\right)-\left(\bar{y}_{N E, P}-\bar{y}_{N E, T}\right)}{\left(\overline{G J}_{E, P}-\overline{G J}_{E, T}\right)-\left(\overline{G J}_{N E, P}-\overline{G J}_{N E, T}\right)}
$$

The numerator corresponds to the difference-in-difference estimator. The denominator corresponds to the differential entry rate.

The estimates presented in the rest of the article are calculated at different points in the young person's career path. The panel survey collected the situation of young people at three different dates (see below). The month-to-month employment calendar 
reconstructed during this same survey is used to estimate the effect of Garantie jeunes at different points in time during the support process and after leaving the programme (for more details on the estimation methodology, see GAINI et al., 2018). The estimates presented in the third section are controlled for various individual characteristics. The estimation models also include a "local centre" fixed effect.

\section{Data Come from Three Sources}

The evaluation of Garantie jeunes is based on three data sources: the I-Milo database of local centres plus the two sources set up for the purposes of the evaluation: a census conducted among local centre advisers of young people eligible for Garantie jeunes (Edipe) and a panel survey of young beneficiaries and non-beneficiaries of Garantie jeunes.

The I-Milo data comes from the application used by all local centre advisers for maintaining the young people's case files. This administrative database lists the young people in contact with the local centres, whether or not they are in Garantie jeunes. It is used to describe a large number of the young people's individual characteristics, the actual steps taken within the structure or with its partners, the services that the young people can make use of, and the professional situations that they declare to their adviser.

However, the I-Milo information system is not sufficient on its own to identify young people who meet the eligibility criteria for Garantie jeunes. The CEdipe platform was therefore set up. The local centres were asked to identify the young adults potentially eligible for Garantie jeunes with whom they were in contact between June and December 2014. The advisers also indicated the difficulties that they believed the young people face. This system enabled more than 20,000 young people to be identified in the pilot and control areas.

Finally, a panel survey was conducted on a sample of young people in contact with a local centre on three occasions between June and December 2014. The sample included a representative sub-sample of young participants of Garantie jeunes in the phase 1 areas of the trial who entered the programme between June and December 2014. For the purposes of the counterfactual evaluation, the survey sample also included a sub-sample of young people identified as eligible on the Edipe platform and a subsample of non-eligible young people, in both the phase 1 pilot areas and the control areas. All of these young people were questioned about their career path (the survey included a retrospective employment calendar), the support they had received, their personal and family situation, their living conditions, their autonomy, etc. The young people were questioned three times at six-month intervals: the first time between May and July 2015, then between November 2015 and February 2016, and finally between May and July 2016. The effects can thus be estimated at three different points in time: on average it was then eleven months, seventeen months and twenty-two months since the participants entered Garantie jeunes (see Table 1). 
TABLE 1 - Situation at the Time of the Three Surveys of Young People in the Sub-Sample Used for the Evaluation

\begin{tabular}{|c|c|c|c|c|c|c|c|c|c|c|c|c|}
\hline & \multicolumn{4}{|c|}{ Survey 1} & \multicolumn{4}{|c|}{ Survey 2} & \multicolumn{4}{|c|}{ Survey 3} \\
\hline & \multicolumn{4}{|c|}{ May 2015 - July 2015} & \multicolumn{4}{|c|}{ November 2015 - Feb 2016} & \multicolumn{4}{|c|}{ May 2016 - July 2016} \\
\hline & $\begin{array}{c}\text { Eligible } \\
\text { pilot }\end{array}$ & $\begin{array}{l}\text { Eligible } \\
\text { control }\end{array}$ & $\begin{array}{l}\text { Non } \\
\text { eligible } \\
\text { pilot }\end{array}$ & $\begin{array}{c}\text { Non } \\
\text { eligible } \\
\text { control }\end{array}$ & $\begin{array}{c}\text { Eligible } \\
\text { pilot }\end{array}$ & $\begin{array}{l}\text { Eligible } \\
\text { control }\end{array}$ & $\begin{array}{c}\text { Non } \\
\text { eligible } \\
\text { pilot }\end{array}$ & $\begin{array}{l}\text { Non } \\
\text { eligible } \\
\text { control }\end{array}$ & $\begin{array}{c}\text { Eligible } \\
\text { pilot }\end{array}$ & $\begin{array}{l}\text { Eligible } \\
\text { control }\end{array}$ & $\begin{array}{l}\text { Non } \\
\text { eligible } \\
\text { pilot }\end{array}$ & $\begin{array}{l}\text { Non } \\
\text { eligible } \\
\text { control }\end{array}$ \\
\hline $\begin{array}{l}\text { No. of } \\
\text { respondents to } \\
\text { the } 3 \text { surveys } \\
\text { (total: } 6,887 \text { ) }\end{array}$ & 1,886 & 2,364 & 1,198 & 1,439 & 1,886 & 2,364 & 1,198 & 1,439 & 1,886 & 2,364 & 1,198 & 1,439 \\
\hline $\begin{array}{l}\text { Of which } \\
\text { entered GJ on } \\
\text { the survey date } \\
(\%)\end{array}$ & 67.2 & 8.5 & 5.8 & 1.2 & 68.7 & 13.9 & 8.3 & 2.4 & 69.5 & 16.9 & 9.4 & 3.4 \\
\hline $\begin{array}{l}\text { No. of months } \\
\text { since the } \\
\text { participants } \\
\text { entered GJ }\end{array}$ & 10.7 & 2.8 & 6.4 & 2.2 & 16.5 & 6.4 & 9.3 & 5.3 & 21.8 & 10.2 & 13.3 & 8.2 \\
\hline
\end{tabular}

Interpretation: 1,886 young people identified as eligible via the (Edipe platform in the pilot areas responded to the three surveys. At the time of the first survey, $67.2 \%$ of them had entered Garantie jeunes (whether they were still in the scheme or had left it).

Field: 6,887 respondents to the three surveys, identified as eligible or non-eligible between June and December 2014. The pilot areas correspond to the first 10 areas to have implemented Garantie jeunes.

Sources: I-Milo, Youth follow-up surveys to the Garantie jeunes trial, DARES processing.

The young people in the sample are a vulnerable population facing occupational and/or social difficulties. In addition, they were difficult to contact because they often change their contact details and tend, in general, to respond less well to surveys. A variety of means were used to optimise response rates and thus limit bias. Approximately $70 \%$ of the young people surveyed responded to the first survey, and the attrition rate was approximately $20 \%$ at each survey point. ${ }^{1}$ Out of the initial sample of 17,330 young people, 8,190 - nearly half - responded to all three surveys. Of these, 6,177 were part of the representative sub-sample of youth who entered Garantie jeunes between June and December 2014, and 6,887 were part of the sub-sample used to conduct the evaluation.

\section{Main Descriptive Results for the Target Groups, the Support, and the Career Paths}

Garantie jeunes was started in October 2013, initially on a trial basis in ten areas, corresponding to forty-one local centres. It was then extended to other areas in successive waves from January 2015 , and was rapidly ramped up. The system was

1. These response rates are higher than those observed in the RCA evaluation survey and were on the same order of magnitude as those observed in the survey to evaluate "jobs of the future" (emplois d'avenir). 
generalised to the entire country on 1 January $2017 .{ }^{2}$ Garantie jeunes has become a universal right for all young people between age 16 and 26 who meet the criteria for access, i.e. who are not in employment, education, or training and who are in a precarious situation. Between the start of the trial and the end of 2017, some 178,000 young people had joined the programme.

\section{Beneficiaries of Garantie Jeunes: Particularly Disadvantaged Situations}

The programme targets a specific population: young people who are not in employment, education, or training, and who are in a situation of financial insecurity, i.e. who do not enjoy financial support from their parents and have few resources. A quantitative analysis of the profile of Garantie jeunes participants reveals a group of fragile young people who have experienced a series of difficulties in their lives.

Of the young people who joined Garantie jeunes before the end of 2016, 45\% were female (source: I-Milo). Entrants to the programme were on average 21 years old. $6 \%$ had a foreign nationality, and $38 \%$ had at least one foreign parent. The fact that they live in one of France's priority urban districts did not directly form part of the targeting, but young people in these areas, who on average have fewer qualifications than others, access Garantie jeunes more often: a quarter live in a priority district, compared with only $9 \%$ of all young people aged between 16 and 25. Participants in Garantie jeunes have a low level of education: $30 \%$ had stopped their initial studies during lower secondary school or before achieving a vocational diploma (compared to $6 \%$ of all young people aged 16 to 25 ), $40 \%$ have a level $\mathrm{V}$ qualification (CAP [Certificat d'aptitude professionnelle] or BEP [Brevet d'études professionnelles] vocational diploma, validated or not), and 30\% went to the last year of upper secondary school (the high school baccalaureate diploma, the "Bac", validated or not). Fewer than $2 \%$ had gone on to tertiary education (Bac + at least two more years) or more, compared with $44 \%$ of all young people aged 16 to $25.18 \%$ of participants had halted their studies before the age of 17 (compared to 5\% of 16-25 years old).

The panel survey of participants showed that they often experience situations of isolation. They have lost relations with their families more often than have other people in their age group, especially with their fathers: $14 \%$ have a father who is dead or unknown, and $21 \%$ of the rest have had no contact with the father during the year. In the general population of youth aged 18 to $24,7 \%$ of young people have a deceased or unknown father, and $7 \%$ have no further contact with their father (from the ENRJ 2014 survey).

Participants encounter peripheral barriers to employment. $22 \%$ of the beneficiaries surveyed believe that mobility problems (means of transport, driving licenses) pose the main difficulties in obtaining a job. Only $30 \%$ had a driving licence when they joined Garantie jeunes (compared to around $70 \%$ of young people in this age group).

2. In accordance with the Law of August 2016 on work, modernising the social dialogue and securing career paths. 
A quarter of them have already experienced significant housing difficulties during their lives, and $6 \%$ were in an unstable housing situation or were homeless in the months preceding their entry into Garantie jeunes.

\section{Support for Participants is Intensive, Particularly at the Beginning of the Programme}

The support lasts twelve months, with a possible renewal for a maximum of six months (but which is very rare in practice). Early departures are possible, particularly if the young person abandons the scheme or moves or is excluded for not respecting the conditions of the contract signed with the local centre. $23 \%$ of the young people who entered Garantie jeunes by end 2015 left the scheme prematurely, on average after eight months: $43 \%$ of these early departures were motivated by a failure to comply with commitments, and $21 \%$ because the young person gave up (which may follow access to employment or training).

The first two months of support are characterised by numerous group workshops that each cohort of young people attend full-time (Figure 1). On average, the young people benefit from one individual interview per month over the twelve months following their entry into Garantie jeunes. These interviews are more frequent at the start of the programme.

\section{FIGURE 1 - Interviews, Workshops and Collective Information Sessions Involving Participants} Month by Month Before and After Entering Garantie Jeunes

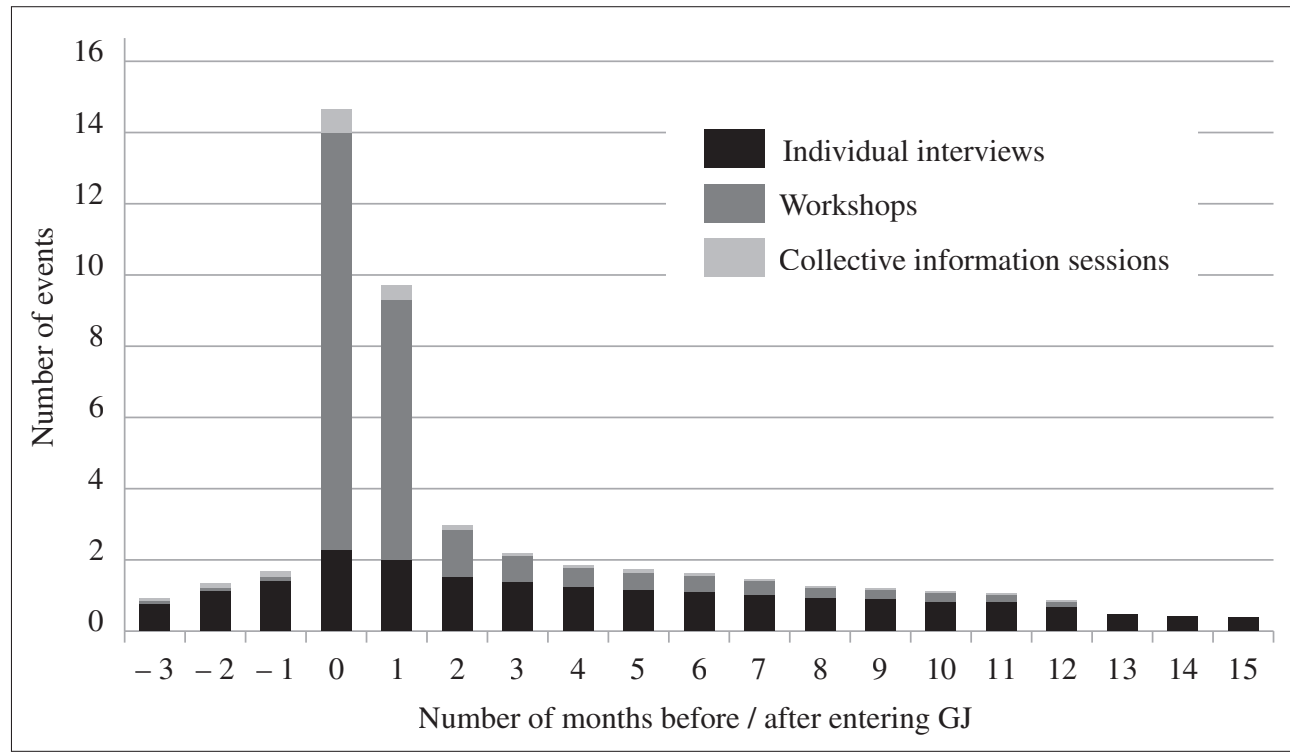

Interpretation: In the month following entry into Garantie jeunes (month 1), beneficiaries have an average of 2 individual interviews and attend 8 workshops or group information sessions.

Field: Young people who have joined Garantie jeunes by end 2015.

Source: I-Milo, DARES processing. 
FIgURE 2 - Garantie Jeunes Stipend Received by Participants in the Twelve Months after Programme Entry

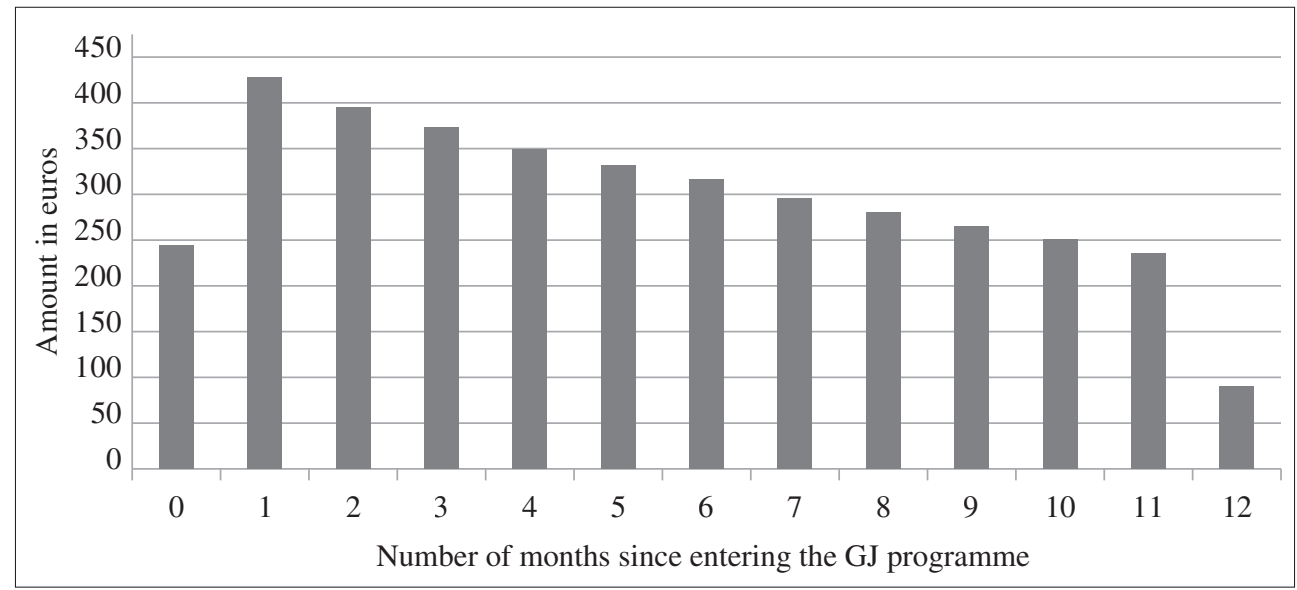

Interpretation: Young people benefit on average from 400 euros of the Garantie jeunes stipend in the second month after entering Garantie jeunes (month 2). The amounts for the months of entry (month 0) and exit (month 12) are much lower because the stipend, calculated on a pro rata temporis basis, corresponds to incomplete months.

Field: Stipends received during the first twelve months, starting from the month of GJ application, for young people entering GJ by end 2015 .

Source: I-Milo, DARES processing.

Beneficiaries receive a stipend capped at the amount corresponding to the RSA social welfare benefit for a single person, after deduction of the housing benefit, i.e. approximately 470 euros per month in 2016 . The stipend is linearly degressive beyond 300 euros of monthly earned income and is no longer paid when this income reaches 80 per cent of the gross minimum wage (SMIC). At the beginning of support, the beneficiaries very often receive the maximum amount of the stipend, and then as support goes on, the average amount decreases with the increase in other income, as well as with - a priori to a lesser extent - sanctions and early exits from the programme (Figure 2). Over the entire support period, young people receive an average of 3,900 euros.

\section{Participants' Trajectories: Gradual Professional Integration and Increased Autonomy}

Employment among the young beneficiaries increased after entry into the programme, particularly long-term employment. After the first two months of support, i.e. when the young people have completed the full-time collective support at the local centre, $45 \%$ of them questioned in the panel survey say they have worked at least one hour during the month (including internships, temporary work and immersions) (Figure 3). This proportion then remains stable until the end of the support, but the intensity of employment increases: the proportion of young people declaring that they have worked all month increases from $11 \%$ two months after entering Garantie jeunes 
FIgURE 3 - Share of Young Beneficiaries Having Worked at Least One Hour in the Month and the Entire Month (Including Internships, Temping, Immersions)

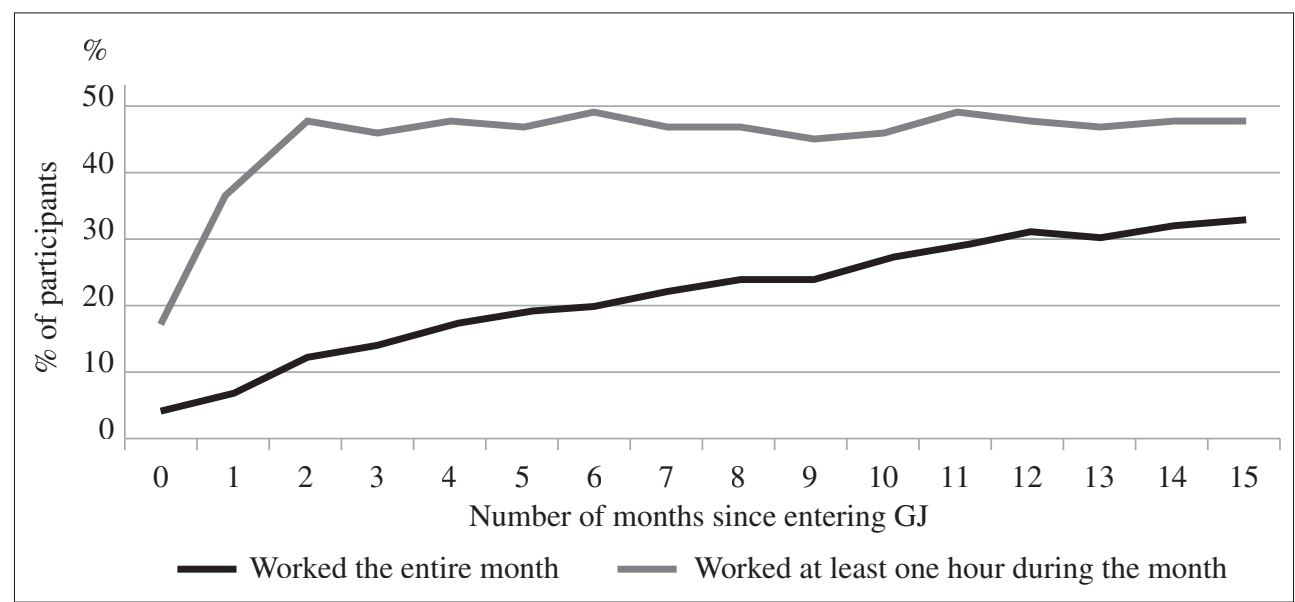

Interpretation: In the third month after entering Garantie jeunes, $46 \%$ of participants worked at least one hour in the month, and $14 \%$ worked the entire month. Employment here corresponds to employment in the broadest sense. It includes internships, temporary work and immersions.

Field: Young participants who joined Garantie jeunes between June and December 2014 in the pilot areas in phase 1 of the trial and who answered the 3 surveys.

Source: Youth follow-up surveys to the Garantie jeunes trial, DARES processing.

to $29 \%$ upon leaving the scheme. Then, over the few months following departure from the programme, the proportion of young people who worked at least one hour during the month remains stable, while the proportion of young people who worked the entire month continues to rise.

Long-term employment is increasing: the proportion of young beneficiaries who say they are mainly in long-term jobs rose from $8 \%$ in the first survey (on average nine months after entry into Garantie jeunes) to $13 \%$ in the second survey (fifteen months after entry) and $16 \%$ in the third survey (twenty months).

Half of the young people report that their financial situation has improved since joining Garantie jeunes and one-third say it has remained the same. However, the financial situation of the majority of beneficiaries remained difficult. $38 \%$ said they have to be careful, and $32 \%$ said they have difficulty or cannot manage without getting into debt.

The young beneficiaries are becoming more independent. The proportion of those with a driver's licence increased from $38 \%$ at the time of the first survey to $48 \%$ a year later. However, this proportion is still much lower than for this age group as a whole. The young people are also increasingly autonomous in terms of housing. One year before the first survey, a few months before they joined Garantie jeunes, two-thirds of them lived with their parents. Two years later, only half of them were still living with their parents. The proportion of young people renting, sharing or owning their own home rose from $19 \%$ one year before the first survey to $37 \%$ upon the third survey. 
The situation of young Garantie jeunes participants has therefore evolved rather positively since the programme was introduced, in terms of autonomy and access to employment. However, these descriptive elements are insufficient in themselves to conclude that Garantie jeunes has had a positive impact on participants' trajectories. This is the subject of the counterfactual evaluation presented in the following section.

\section{Results of the Impact Assessment of Garantie Jeunes on Participants' Trajectories}

This section presents the results of the impact assessment on the career path of young beneficiaries identified between June and December 2014 in the phase 1 trial areas. We also estimate the effect that entry into Garantie jeunes had on the intensity of support for participants.

\section{An Important Impact of Garantie Jeunes on Long-Term Employment for Beneficiaries}

The difference-in-difference estimates of the impact of Garantie jeunes rely on several assumptions (see section presenting the assessment strategy). The first, the common gap hypothesis, is to assume that the groups of ineligible youth make possible a good estimate of the structural gap between the pilot areas and the control areas. This hypothesis cannot be directly verified in the absence of data on the career paths of young people prior to the implementation of Garantie jeunes. However, in order to provide convincing evidence for this hypothesis, it was tested on a certain number of predetermined variables prior to the introduction of Garantie jeunes (gender, age, driving licence, national origin, relationship with parents, housing difficulties, place of residence, and educational level). Estimates on these variables indicate a structural gap between eligible youth in the pilot and control areas that is corrected by the difference-in-difference estimation.

Statistical contamination requires making a hypothesis about the effect that Garantie jeunes has had on the young people in the control areas and on the ineligible young people who entered the programme. The hypothesis adopted is that the effect of Garantie jeunes was homogeneous. It consists of assuming that the impact of Garantie jeunes on beneficiaries is the same at the time of each survey, regardless of the characteristics of the young people or the length of time spent in the programme. For example, the impact of Garantie jeunes on beneficiaries in the pilot areas who, at the time of the first survey, had been in the programme for an average of eleven months should be the same as that on participants in the control areas who had received support for an average of three months. This is a strong assumption, and it is unlikely to be met, as the impact of the scheme undoubtedly varies during the course of the support. In particular, it is a priori stronger at the beginning of the programme when the young people benefit 
from numerous immersions. However, it can be assumed that the bias incurred is small, as the statistical contamination of the control populations is low (Table 1). Moreover, the bias is certainly smaller than that of the difference-in-difference estimator relative to the rate of entry into Garantie jeunes, which implicitly assumes that the programme has had no effect on "contaminated" youth.

The effects on employment are examined using four variables of interest: total employment along with various breakdowns of this, including:

- Supported employment (excluding work-study), internships, immersions, and civic service;

- Non-long-term employment (fixed-term contract of less than six months, temporary work, etc., excluding supported employment, internships, and civic service);

- Long-term employment (permanent and fixed-term contracts of six months or more, including work-study contracts, excluding supported employment).

The impact is assessed at the time of the various surveys.

The estimates point to a significant effect on participants' employment rates: +9.9 percentage points at survey $1,+14.9$ percentage points at survey 2 , and +11.4 percentage points at survey 3 (Table 2 ). ${ }^{3}$ This means, for example, that at the time of the first survey the employment rate of $29.9 \%$ of participants would have been $20.0 \%$ without Garantie jeunes. This impact on employment is due to the effect on long-term employment, which remains almost stable between survey 2 (+13.1 points) and survey 3 ( +12.1 points).

Given the low average employment rates (total and long-term employment) of the young people targeted by the programme, the impacts thus highlighted are rather strong. This is all the more noteworthy as it can be confirmed that the observed impact mainly affects long-term employment and much less employment of under six months, even though this is easier and more common to find. Likewise, the positive effect on Garantie jeunes beneficiaries does not stem from the greater use of supported employment to place them in work. Since young people are in less of a hurry thanks to the stipend, they have more time to find good quality jobs.

The impact of Garantie jeunes is estimated on the beneficiaries of the programme who constitute a potentially specific sub-population of young people among those eligible for the programme. Entry into Garantie jeunes is based on eligibility criteria, but also on the fact that the young person volunteers to take part and that the local centre adviser actually proposes the scheme to him or her and presents his or her file to a commission responsible for assignments and follow-up. The Edipe platform has made it possible to collect data from the local centre advisers that indicate the social and professional difficulties they believe the young people face. This data provides information on the profile of the young people who ultimately enter the scheme. It appears that being able to stick to full-time support has played a role in access to the

3. The intention to treat estimates (difference-in-difference estimator) can be found in the appendix. 
TABLE 2 - Impact of Garantie Jeunes on the Employment Rate of Participants

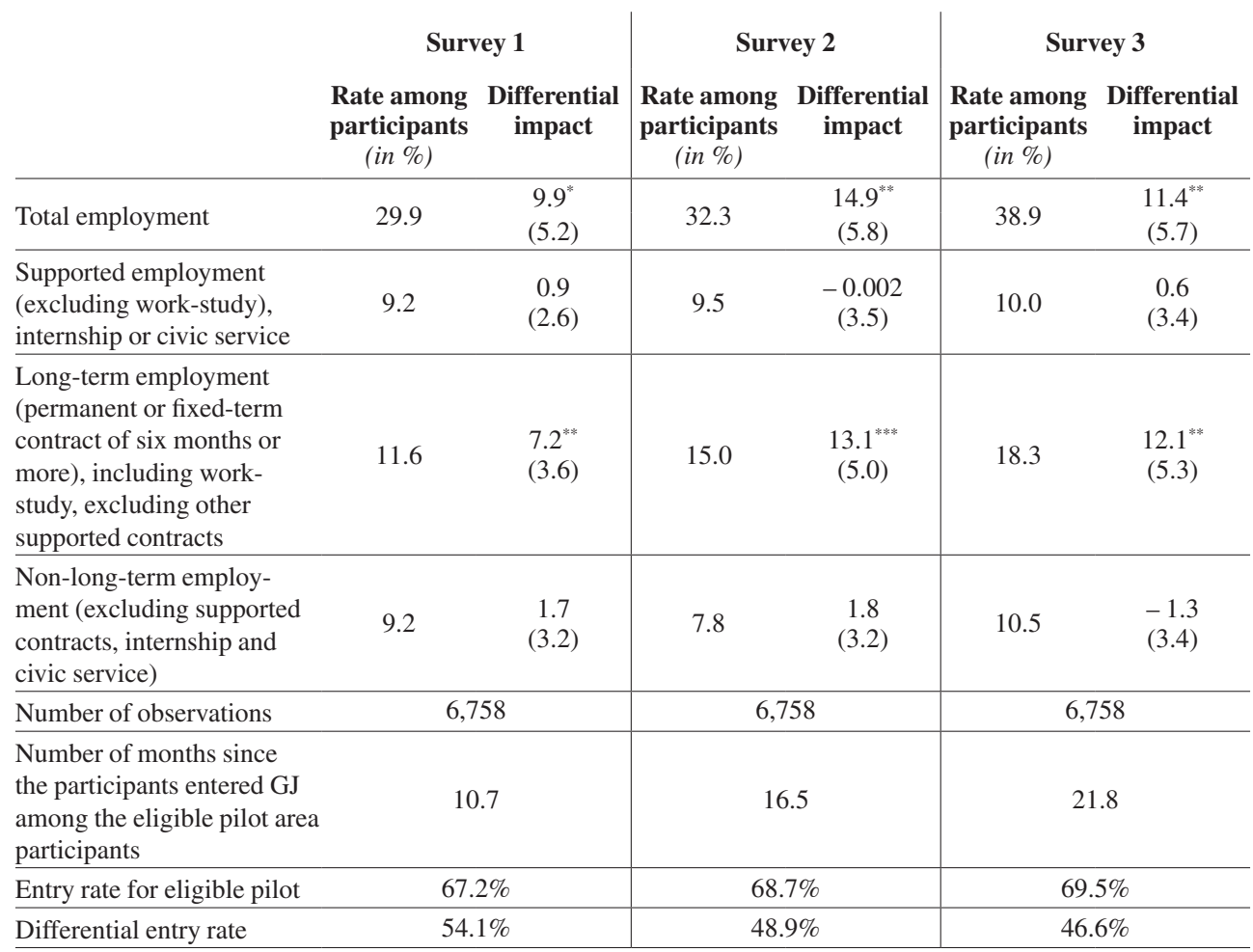

***: significant at the $1 \%$ threshold; **: significant at the $5 \%$ threshold; *: significant at the $10 \%$ threshold.

Standard deviations in brackets.

Interpretation: At the first survey, the impact of Garantie jeunes was significant at the $10 \%$ threshold on the employment rate of young beneficiaries. At the time of this survey, the implementation of Garantie jeunes in the phase 1 trial areas resulted in an increase in the proportion of young beneficiaries in employment of 9.9 percentage points compared to what would have occurred without Garantie jeunes. The employment rate of $29.9 \%$ would therefore have been only $20.0 \%$ without Garantie jeunes. At the time of this initial survey, the participants had been in the programme for an average of 10.7 months.

Field: 6,758 respondents to the three surveys, identified as eligible or non-eligible between June and December 2014, in the pilot areas (areas in phase 1 of the trial) and in the control areas.

Sources: I-Milo, Youth follow-up surveys to the Garantie jeunes trial, DARES processing.

programme. Among the young people identified as potentially eligible, $16 \%$ could handle support only with "some difficulty" or "great difficulty" according to the information provided by the local centre advisers. The proportion of young people who were "supportable" only with "some difficulty" or "great difficulty" was lower among the actual participants (13\% among participants, 23\% among eligible non-participants). It also seems that slightly fewer participants (proportionally) had health problems (physical or psychological). On the other hand, they were more likely to have problems with soft skills and to have a level of qualifications considered insufficient. They were also more likely to have housing problems, family problems, and low self-esteem. 


\section{The Impact on Employment Varies over Time}

The retrospective employment calendar provided an opportunity to flesh out the estimates of the impact on employment. It reconstructs, on a month-by-month basis, the proportion of young people who worked at least once in the month or for the entire month. This makes it possible to estimate the effect of Garantie jeunes at different times during the scheme and after leaving it. However, the information on employment found in the calendar is not as precise as the employment situations described at the time of each survey. The concept of employment in the calendar includes all forms of employment, including internships, immersion periods, temporary work, civic service, supported contracts, and traditional job contracts. This analysis highlights that there is substantial variability in the impact on having worked at least one hour in the month based on the timing of the support. The impact is significant at the start of the programme, continues in the middle of the programme, is not significant in the last two months of support, and rises significantly just after leaving the programme (Table 3).

The significant impact estimated in the first three months of the programme is undoubtedly linked to the very high intensity of the support during the first few weeks. There is in particular a significant effort on immersions during this period. The logic of "work first" leads young people in Garantie jeunes to be in employment situations more quickly than young people who are not beneficiaries.

While the impact diminishes during the remainder of the programme, the exit appears to function as a second "trigger" moment. Several factors could explain this rebound at the end of the period. It could be because the beneficiaries, seeing the end

TABLE 3 - Impact of Garantie Jeunes on Having Worked at Least One Hour in the Month, over Different Periods after Entering the Programme

\begin{tabular}{l|cc} 
& \multicolumn{2}{|c}{$\begin{array}{c}\text { Variable of interest: } \\
\text { worked at least one hour during the month }\end{array}$} \\
\hline Number of months since entering GJ & $\begin{array}{c}\text { Observed rate among } \\
\text { participants }(\text { in } \%)\end{array}$ & Impact on participants \\
\hline 3 months or less & 36 & $\begin{array}{c}26.1^{* * * *} \\
(7.3)\end{array}$ \\
\hline From 4 to 9 months & 45 & $\begin{array}{c}18.4^{* * *} \\
(5.4)\end{array}$ \\
\hline From 10 to 12 months & 46 & -6.6 \\
\hline From 13 to 16 months & 47 & $\begin{array}{c}22.2^{* * *} \\
(7.6)\end{array}$ \\
\hline 17 months and over & 51 & 6.6 \\
\hline
\end{tabular}

***: significant at the $1 \%$ threshold; **: significant at the $5 \%$ threshold; *: significant at the $10 \%$ threshold.

Interpretation: Between months 4 and 9 after entering Garantie jeunes, $45 \%$ of young people worked at least one hour in the month. The impact of Garantie jeunes on the average proportion of young beneficiaries who worked at least one hour is +18.4 percentage points, which is significant.

Field: Respondents to the three surveys, identified as eligible or non-eligible between June and December 2014 in the pilot areas (areas in phase 1 of the trial) and in the control areas.

Source: Youth follow-up surveys to the Garantie jeunes trial, DARES processing. 
of the scheme approach, remobilise and seize all possible job opportunities, whereas the period preceding the exit might be spent more on the job search, but also, in some cases, on certain investments (training, obtaining a driving licence, etc.). Another hypothesis - not to the exclusion of the previous one - is that the local centre advisers step up their placement efforts for young beneficiaries as the end of the programme approaches.

Statistical contamination also affects the employment calendar data. However, since the effect is estimated at different points in time during the support, the assumption of homogeneity here does not assume that the effect is constant over the support period. Rather, it assumes an identical effect on eligible and non-eligible young people, whether they are in a pilot area or a control area. Here too, the bias incurred in case this hypothesis is not met could be considered to be small due to the low rate of contamination.

\section{What Additional Support in the Local Centre for Participants?}

The effect of Garantie jeunes on access to employment can be interpreted as the impact of the additional support provided to young people who have joined the programme during their support period (which is not limited to the twelve months in the scheme) compared to the "traditional" support they would have received if Garantie jeunes had not been introduced. In particular, some young people would have entered the Civis programme and would also have benefited from individual follow-up; they would have attended group workshops and taken part in immersions, and some of them would have received an interstitial stipend. It is possible to appreciate the support provided to young people through Garantie jeunes, at least in part, from the individual interviews, workshops, immersions, and stipends recorded in the local centres' information systems. At the same time, the informal exchanges between the young people and advisers are not recorded (yet there are many such exchanges in Garantie jeunes); the same is true of the support that young people may have received in other structures, such as France's Pôle emploi job centres, for example.

Estimates indicate that the introduction of Garantie jeunes has indeed strengthened support for participants, particularly towards the start of the scheme. During the first three months, young people in Garantie jeunes benefited from an additional individual interview each month (1.7 instead of 0.7, as indicated in Table 4), as well as five workshops, two days of immersion, and an additional stipend of 220 euros (this amount may seem low compared to the maximum amount of the stipend, but this calculation includes the stipend for the first month in Garantie jeunes, which, calculated on a pro rata temporis basis, is often not the full amount). Thereafter, between four and nine months after entering the programme, the additional monthly support is less substantial: 0.3 individual interview and 0.7 day of immersion more, but 0.4 workshop less (these are mainly provided during the first weeks of collective support). The financial support represented by the stipend continues over the twelve 
TABLE 4 - Estimates of the Monthly Support Differential Enjoyed by Young People in Garantie Jeunes, at Different Times during the Programme and upon Leaving it

\begin{tabular}{|c|c|c|c|c|c|c|c|c|}
\hline \multirow[b]{2}{*}{$\begin{array}{l}\text { Number of } \\
\text { months since } \\
\text { entering GJ }\end{array}$} & \multicolumn{2}{|c|}{ Individual interviews } & \multicolumn{2}{|c|}{ Workshops } & \multicolumn{2}{|c|}{$\begin{array}{c}\text { Immersion days } \\
\text { (1) }\end{array}$} & \multicolumn{2}{|c|}{$\begin{array}{l}\text { Stipend } \\
\text { (in euros) }\end{array}$} \\
\hline & $\begin{array}{c}\text { Monthly } \\
\text { average of } \\
\text { participants }\end{array}$ & $\begin{array}{c}\text { Effect on } \\
\text { participants }\end{array}$ & $\begin{array}{c}\text { Monthly } \\
\text { average of } \\
\text { participants }\end{array}$ & $\begin{array}{c}\text { Effect on } \\
\text { participants }\end{array}$ & $\begin{array}{c}\text { Monthly } \\
\text { average of } \\
\text { participants }\end{array}$ & $\begin{array}{c}\text { Effect on } \\
\text { participants }\end{array}$ & $\begin{array}{c}\text { Monthly } \\
\text { average of } \\
\text { participants }\end{array}$ & $\begin{array}{c}\text { Effect on } \\
\text { participants }\end{array}$ \\
\hline $\begin{array}{l}\text { From } 0 \text { to } 3 \\
\text { months }\end{array}$ & 1.7 & $\begin{array}{l}1.0^{* * * *} \\
(0.2)\end{array}$ & 5.3 & $\begin{array}{l}5.2^{* * *} \\
(0.3)\end{array}$ & 2.5 & $\begin{array}{l}2.1^{* * * *} \\
(0.5)\end{array}$ & 265.9 & $\begin{array}{c}220.0^{* * * *} \\
(11.4)\end{array}$ \\
\hline $\begin{array}{l}\text { From } 4 \text { to } 9 \\
\text { months }\end{array}$ & 1.0 & $\begin{array}{l}0.3^{* *} \\
(0.1)\end{array}$ & 0.4 & $\begin{array}{l}-0.4^{* *} \\
(0.2)\end{array}$ & 1.4 & $\begin{array}{l}0.7^{* * * *} \\
(0.2)\end{array}$ & 351.6 & $\begin{array}{l}369.0^{* * * *} \\
(12.4)\end{array}$ \\
\hline $\begin{array}{l}\text { From } 10 \text { to } 12 \\
\text { months }\end{array}$ & 0.8 & $\begin{array}{c}0.2 \\
(0.1)\end{array}$ & 0.2 & $\begin{array}{c}0.3 \\
(0.3) \\
\end{array}$ & 0.7 & $\begin{array}{c}0.3 \\
(0.3) \\
\end{array}$ & 292.3 & $\begin{array}{c}290.5^{* * * *} \\
(19.0)\end{array}$ \\
\hline $\begin{array}{l}\text { From } 13 \text { to } 16 \\
\text { months }\end{array}$ & 0.3 & $\begin{array}{c}-0.3^{* *} \\
(0.1)\end{array}$ & 0.03 & $\begin{array}{l}0.04 \\
(0.1)\end{array}$ & 0.1 & $\begin{array}{l}-0.2 \\
(0.2)\end{array}$ & 36.3 & $\begin{array}{l}1.7 \\
(9.5)\end{array}$ \\
\hline $\begin{array}{l}17 \text { months } \\
\text { and over }\end{array}$ & 0.2 & $\begin{array}{l}-0.1^{* * *} \\
(0.04)\end{array}$ & 0.02 & $\begin{array}{l}-0.04 \\
(0.03)\end{array}$ & 0.1 & $\begin{array}{l}-0.1 \\
(0.1)\end{array}$ & 4.5 & $\begin{array}{l}-2.6 \\
(3.4)\end{array}$ \\
\hline
\end{tabular}

$* * *$ : significant at the $1 \%$ threshold; **: significant at the $5 \%$ threshold; *: significant at the $10 \%$ threshold.

Standard deviations in parentheses.

(1) Periods of situational exercises in the workplace and other equivalent arrangements.

Interpretation: It is estimated that young people in Garantie jeunes benefit from 1.0 additional individual interview per month over the first three months compared to the situation without the implementation of Garantie jeunes. They have an average of 1.7 individual interviews per month, compared to 0.7 if Garantie jeunes had not been put in place.

Field: Respondents to the three surveys, identified as eligible or non-eligible between June and December 2014 in the pilot areas (areas in phase 1 of the trial) or control areas.

Sources: I-Milo, Youth follow-up surveys to the Garantie jeunes trial, DARES processing.

months of support, with a reduction in the last two months due to the fact that the young people are more employed and that some participants have left the scheme early. This reduction is also due to the fact that the last month's stipend is often incomplete for the same reasons as those mentioned for the month of entry. Upon leaving the scheme, young people in Garantie jeunes are less often interviewed individually than at other times in the scheme.

What accounts for the effectiveness of Garantie jeunes observed here for this sample of participants? It is difficult to attribute the impact to one specific new component of the programme: is it due to the increased intensity, to the collective support that creates a dynamic of mutual aid among the young people being supported, to the stipend that supports their efforts over time, or to its overall philosophy that puts the professional situation at the forefront, ahead of all other interventions?

The results reported here concern the first cohort of Garantie jeunes beneficiaries who entered in the first areas that volunteered in 2013. These results confirmed several studies on this same programme (FARVAQUE et al., 2016; LOISON-LERUSTE et al., 2016), which the Law of 8 August 2016 generalised to the whole of France. As with all evaluations carried out on pioneering or trial programmes, strictly speaking the results apply 
only to this trial phase. It could be argued in particular that the energy of its pioneers and their belief that an innovative project will bring benefits does not always foreshadow the results of its successors. However, the philosophy and professional activities of Garantie jeunes were framed by very precise and relatively well-defined specifications (FARVAQUE et al., 2016) and were the subject of a particularly substantial design and training effort. If the programme's spirit and method are regularly reincorporated and reworked by professionals in the field, it is likely that this effectiveness will be sustainable. Moreover, the deployment of Garantie jeunes has been presented and felt more as a prototyping phase than as some pure experiment that is likely to lead to the programme's possible abandonment (SIMHA, 2017). All the stakeholders in the field (local decision-makers and professionals) were thus fully mobilised from the first months of Garantie jeunes, as in any other common law programme, which lends the results of the evaluation a more convincing degree of external validity.

The impact assessment of the Garantie jeunes programme should therefore be pursued both qualitatively and quantitatively. New ex-post evaluations could thus make use of the period of the programme's gradual roll-out (2013-2016) throughout the country.

\section{REFERENCES:}

Aeberhardt, R., Chiodi, V., Crépon, B., Gaini, M., and Vicard, A. (2014). « Du revenu contractualisé d'autonomie à la Garantie jeunes: les enseignements d'une expérimentation. » In J. Bérard. and M. Valdenaire, De l'éducation à l'insertion: dix résultats du Fonds d'expérimentation pour la jeunesse. Paris: La Documentation française.

BLACHE, G., GreCo, D. (2017). «L'accompagnement intensif des jeunes demandeurs d'emploi (AIJ). » Éclairages et synthèses, no 28, Pôle emploi.

Blasco, S., Crépon, B., Skandalis, D., Uhlendorff, A., Alberola, E., and Aventur, F. (2015). «Club Jeunes Chercheurs d'Emploi. Evaluation d'une action-pilote. » Études et Recherches, no 5, Pôle Emploi.

CARD, D., KLuve, J., and Weber, A. (2018). "What Works? A Meta-Analysis of Recent Active Labor Market Program Evaluations.” Journal of the European Economic Association, (16)3, 894-931.

De Chaisemartin, C., D'haultfoeuille, X. (2018). “Fuzzy Differences-in-Differences.” The Review of Economic Studies, (85)2, 999-1028.

Crepon, B., Duflo, E., Gurgand, M., Rathelot, R., and Zamora, P. (2011). « L'accompagnement des jeunes diplômés demandeurs d'emploi par des opérateurs privés de placement: les enseignements d'une évaluation. » Dares Analyses, no 94.

Farvaque, N., Kramme, C., and Tuchszirer, C. (2016). La Garantie jeunes du point de vue des missions locales : un modèle d'accompagnement innovant, mais source de bouleversements organisationnels. Rapport de recherche du Centre d'études de l'emploi et du travail, no 102. 
Gaini, M., Guillerm, M., Hilary, S., Valat, E., and Zamora, P. (2018). Résultats d'évaluation statistique de l'impact de la Garantie jeunes. Rapport final d'évaluation de la Garantie jeunes. Comité scientifique en charge de l'évaluation de la Garantie jeunes, Appendix 5.

Gautié, J. (2018). Rapport final d'évaluation de la Garantie jeunes. Comité scientifique en charge de l'évaluation de la Garantie jeunes.

Loison-Leruste, M., Couronné, J., and Sarfati, F. (2016). La Garantie jeunes en action: usages du dispositif et parcours de jeunes. Rapport de recherche du Centre d'études de l'emploi et du travail, no 101.

Mendolia, S., Walker, I. (2015). “Do Neets Need Grit?” IZA Journal of Labor Economics, (4) 19 .

Parent, G., Sautory, O., and Desplatz, R. (2013). L'accompagnement des demandeurs d'emploi: enseignements des évaluations. Document d'études, no 178, Dares.

PISSARIDES, CH. A. (2011). "Equilibrium in the Labor Market with Search Frictions.” American Economic Review, (101)4, 1092-1105.

SimHA, J. (2017). « Le laboratoire des politiques publiques. Réflexions sur la Garantie jeunes. » La Vie des idées [online]: http://www.laviedesidees.fr/Le-laboratoire-des-politiques-publiques. html, accessed 2 February 2021.

Wargon, E., Gurgand, M. (2013). Synthèse des travaux sur la « Garantie jeunes ». Rapport au Premier Ministre. 


\section{APPENDIX 1 - ESTIMATED IMPACT OF GARANTIE JEUNES WITH INTENTION to Treat Analysis}

The table below presents estimates of the impact of Garantie jeunes with intention to treat analysis (difference-in-difference estimator), i.e., the effect of being eligible in a pilot area rather than a control area. Due to the statistical contamination of the control populations, the estimator is biased.

The impact assessed in survey 1, on average 10.7 months after entry into Garantie jeunes, shows a statistically significant positive effect on the employment rate of young people identified as eligible in Edipe in the pilot areas (+5.4 percentage points on the total employment rate). In survey 2 , on average 16.5 months after entry into

\section{TABLE - Differential Impact of Garantie Jeunes on the Employment Rate of all Pre-Identified Young People in the Pilot Areas (i.e. Eligible People Listed in Edipe, Whether or not they are Beneficiaries of Garantie Jeunes)}

\begin{tabular}{|c|c|c|c|c|c|c|}
\hline & \multicolumn{2}{|c|}{ Survey 1} & \multicolumn{2}{|c|}{ Survey 2} & \multicolumn{2}{|c|}{ Survey 3} \\
\hline & $\begin{array}{l}\text { Rate of } \\
\text { eligible/pilot } \\
\text { (in \%) }\end{array}$ & $\begin{array}{c}\text { Differential } \\
\text { impact }\end{array}$ & $\begin{array}{l}\text { Rate of } \\
\text { eligible/pilot } \\
\text { (in } \%)\end{array}$ & $\begin{array}{l}\text { Differential } \\
\text { impact }\end{array}$ & $\begin{array}{c}\text { Rate of } \\
\text { eligible/pilot } \\
\text { (in } \%)\end{array}$ & $\begin{array}{c}\text { Differential } \\
\text { impact }\end{array}$ \\
\hline Total employment & 32.5 & $\begin{array}{l}5.4^{* * *} \\
(2.6)\end{array}$ & 36.3 & $\begin{array}{l}7.1^{* * *} \\
(2.7)\end{array}$ & 43.8 & $\begin{array}{l}5.2^{* * *} \\
(2.6)\end{array}$ \\
\hline $\begin{array}{l}\text { Supported employment } \\
\text { (excluding work-study), } \\
\text { internship or civic service }\end{array}$ & 7.6 & $\begin{array}{c}0.5 \\
(1.4)\end{array}$ & 8.8 & $\begin{array}{l}-0.1 \\
(1.7)\end{array}$ & 9.4 & $\begin{array}{c}0.2 \\
(1.6)\end{array}$ \\
\hline $\begin{array}{l}\text { Long-term employment } \\
\text { (permanent or fixed-term } \\
\text { contract of six months or } \\
\text { more), including work-study, } \\
\text { excluding other supported } \\
\text { contracts }\end{array}$ & 14.1 & $\begin{array}{l}4.1^{* *} \\
(1.9)\end{array}$ & 18.9 & $\begin{array}{l}6.4^{* * * *} \\
(2.3)\end{array}$ & 23.2 & $\begin{array}{l}5.3^{* *} \\
(2.4)\end{array}$ \\
\hline $\begin{array}{l}\text { Non-long-term employ- } \\
\text { ment (excluding supported } \\
\text { contract, internship and civic } \\
\text { service) }\end{array}$ & 10.8 & $\begin{array}{c}0.1 \\
(1.7)\end{array}$ & 8.6 & $\begin{array}{c}0.8 \\
(1.6)\end{array}$ & 11.1 & $\begin{array}{l}-0.4 \\
(1.6)\end{array}$ \\
\hline Number of observations & \multicolumn{2}{|c|}{6,758} & \multicolumn{2}{|c|}{6,758} & \multicolumn{2}{|c|}{6,758} \\
\hline $\begin{array}{l}\text { Number of months since } \\
\text { the participants entered GJ } \\
\text { among the eligible pilot } \\
\text { participants }\end{array}$ & \multicolumn{2}{|c|}{10.7} & \multicolumn{2}{|c|}{16.5} & \multicolumn{2}{|c|}{21.8} \\
\hline Entry rate for eligible/ pilot & \multicolumn{2}{|c|}{67.2} & \multicolumn{2}{|c|}{68.7} & \multicolumn{2}{|c|}{69.5} \\
\hline Differential entry rate & \multicolumn{2}{|c|}{54.1} & \multicolumn{2}{|c|}{48.9} & \multicolumn{2}{|c|}{46.6} \\
\hline
\end{tabular}

$* * *$ : significant at the $1 \%$ threshold; **: significant at the $5 \%$ threshold; $*$ : significant at the $10 \%$ threshold.

Standard deviations in parentheses.

Interpretation: The implementation of Garantie jeunes led to a 5.4 percentage point increase in the rate of eligible young people in employment in the pilot areas in phase 1 of the trial at the time of the first survey, when participants had been in the programme for an average of 10.7 months. The $32.5 \%$ employment rate of pre-identified young people in the pilot areas would therefore have been only $27.1 \%$ without Garantie jeunes.

Field: 6,758 respondents to the three surveys, identified as eligible or non-eligible between June and December 2014 in the pilot areas (areas in trial phase 1) and in the control areas.

Sources: I-Milo, Youth follow-up surveys to the Garantie jeunes trial, DARES processing. 
Garantie jeunes, the evaluated impact is positive and very significant: it amounts to +7.1 percentage points on the total employment rate, and +6.4 points on the long-term employment rate. In other words, at the time of survey 2 , the proportion of young people identified as eligible in the pilot areas who were in employment is $36.3 \%$, instead of $29.2 \%$ if Garantie jeunes had not been introduced. Similarly, their share in long-term employment was $18.9 \%$, instead of the $12.5 \%$ that would have been the case without Garantie jeunes. Finally, in survey 3,21.8 months on average after entry into Garantie jeunes, the effect on employment is 5.2 points, which is statistically significant, and is supported by the effect on long-term employment (+5.3 points).

\section{APPENDix 2 - RobuSTness TeSTS OF ESTIMATES}

The table below presents estimates of the effect of Garantie jeunes on beneficiaries according to the model's different specifications.

\section{TABLE - Differential Impact of Garantie Jeunes on the Long-Term Employment Rate of Young Beneficiaries According to Different Specifications of the Model}

Variable of interest: in sustainable employment

\begin{tabular}{lccc} 
Model & Survey 1 & Survey 2 & Survey 3 \\
\hline Model with control variables and local & $7.2^{* * *}$ & $13.1^{* * *}$ & $12.1^{* *}$ \\
centre fixed effects, balanced data & $(3.6)$ & $(5.0)$ & $(5.3)$ \\
\hline Model without control variables & $6.1^{*}$ & $10.5^{* *}$ & $8.9^{*}$ \\
and local centre fixed effects & $(3.6)$ & $(4.3)$ & $(4.8)$ \\
\hline DID estimator relative to the entry rate & $5.8^{* *}$ & $9.2^{* * *}$ & $8.0^{* * *}$ \\
among the eligible people in pilot areas & $(2.8)$ & $(3.4)$ & $(3.4)$ \\
\hline Model with control variables and local & $5.5^{*}$ & $11.2^{* *}$ & $12.1^{* *}$ \\
centre fixed effects, unbalanced data & $(3.3)$ & $(4.5)$ & $(5.3)$ \\
\hline
\end{tabular}

